\title{
Research and Application of Green Lighting in Power Plant
}

\author{
Zixia Cheng ${ }^{1}$, Bingbing $\mathrm{Du}^{1,2, \text { a }}$, Yu Wang ${ }^{3}$, Zhenzhen $\mathrm{Niu}^{2}$, Xiu Zheng ${ }^{1}$ \\ ${ }^{1}$ School of Electricity Engineering, Zhengzhou University, Zhengzhou 450001, China \\ ${ }^{2}$ Henan Province Airport Group Co.,Ltd, Zhengzhou, 451161, China \\ ${ }^{3}$ Bo Hui Fang Zhou Development Co.,Ltd, of Henan Province, Zhengzhou, 450052, China
}

\begin{abstract}
To study the application of green lighting in power plant, this paper based on the analysis and comparison of the technical and economic of lighting source and energy-saving lamps and accessories, recommended the use of high luminous efficiency of lamps and lanterns, to achieve energy-saving effect. From the point of lighting design, through the calculation of the illumination value and the use of reasonable lighting control to achieve the effect of green lighting. By adopting the new energy saving lamps and light sources, the operation cost of the power plant and the lighting energy consumption can be reduced, the project investment and operation cost can be saved, and the social and economic benefits will be obtained.
\end{abstract}

\section{Introduction}

In the past few decades, with the rapid development of economy, energy shortage has become a serious problem; energy conservation has become a hot topic recently. "green lighting project" has been listed as one of the ten key energy-saving projects in our country, it will be used in China's new construction and renovation projects,such as: the efficient energy-saving lighting system, promotion of rare-earth trichromatic fluorescent lamps, high luminous efficiency, long service life of the lamp.

At present,domestic and foreign advocate green lighting, it can improve the efficiency of energy utilization, it is conducive to the improvement of the quality of life and urban ecological environment.It also can save energy, alleviate the pressure of environmental protection, in line with the national industrial policy, to achieve energy-saving and reduce the emissions of contaminants.

This paper mainly studies the application of green lighting in the power plant, and gives its application implementation plan.

\section{Green lighting and energy-saving}

\subsection{The definition of green lighting}

The concept of green lighting was proposed by the national environmental protection agency in early 1990s. Complete green lighting connotation contains 4 indicators: energy saving, environmental protection, safety, comfort, and so on. Energy efficient means to obtain adequate lighting and consume less electricity, resulting in a significant reduction in power plant air pollutant emissions to achieve the purpose of environmental protection; Safe, comfortable refers to the clear, soft light, and harmless light without light pollution, such as ultraviolet rays and glare.

To promote green lighting is the key work of energy saving in our country; it should be advanced technology, reasonable economy, the use of safe, convenient maintenance and management in power engineering design, actively the implementation of green lighting.

\subsection{Lighting energy saving}

At present, the development of Chinese power industry is very fast, but the shortage of power supply and low power efficiency is still severe, which will continue to exist in a considerable period of time in the future. Our lighting electricity largely accounts for the total generating capacity of $10-12 \%$. At present, the power plant $2 / 3$ for thermal power, the main energy for coal. Lighting energy-saving means to reduce emissions of harmful gases such as $\mathrm{CO}_{2}, \mathrm{SO}_{2}, \mathrm{NOx}$, so wo should protect the atmospheric environment from a high degree of awareness and treatment of energy-saving lighting, promoting green lighting project.

In thermal power, for example, the production of $1 \mathrm{kWh}$ of electricity, the pollutants generated to the air is shown in table 1.

The goals of energy saving are to build a high quality, high efficiency, economic and comfortable, safe and reliable, good environment and improve people's quality of life, improve work efficiency, and establish a lighting environment for the protection of physical and mental health. It should use advanced and reasonable lighting design methods, good-quality and efficient lighting equipments, to achieve a good effect in energy saving aspect.

\footnotetext{
a Bingbing Du: 2010dubing666@163.com
} 
Table 1. Pollutants produced.

\begin{tabular}{|c|c|c|c|}
\hline Pollutants & Coal & Fuel & Gas \\
\hline $\mathrm{SO}_{2}$ & $9 \mathrm{~g}$ & $3.7 \mathrm{~g}$ & $0 \mathrm{~g}$ \\
\hline $\mathrm{NOx}$ & $4.4 \mathrm{~g}$ & $1.5 \mathrm{~g}$ & $2.4 \mathrm{~g}$ \\
\hline $\mathrm{CO}_{2}$ & $1100 \mathrm{~g}$ & $860 \mathrm{~g}$ & $640 \mathrm{~g}$ \\
\hline
\end{tabular}

The lighting energy-saving evaluation index is the lighting power density (LPD), the power density of some rooms or places of the power plant should not be greater than the value in table 2 . When the illumination value of the room or place is higher or lower than the corresponding value, the value of the lighting power density should be increased or reduced according to the proportion.

Table 2. Power plant lighting power density.

\begin{tabular}{|c|c|c|c|}
\hline \multirow{2}{*}{$\begin{array}{c}\text { Room or } \\
\text { place }\end{array}$} & \multicolumn{2}{|c|}{$\mathrm{LPD}\left(\mathrm{W} / \mathrm{m}^{2}\right)$} & $\begin{array}{c}\text { Corresponding } \\
\text { illumination } \\
\text { value(lx) }\end{array}$ \\
\cline { 2 - 4 } & $\begin{array}{c}\text { Current } \\
\text { value }\end{array}$ & $\begin{array}{c}\text { Target } \\
\text { value }\end{array}$ & Gas \\
\hline $\begin{array}{c}\text { turbine room } \\
\text { operation } \\
\text { layer }\end{array}$ & 7.0 & 6.0 & 200 \\
\hline $\begin{array}{c}\text { turbine room } \\
\text { bottom, pipe } \\
\text { layer }\end{array}$ & 4.0 & 3.5 & 100 \\
\hline $\begin{array}{c}\text { bottom of } \\
\text { boiler room }\end{array}$ & 5.0 & 4.5 & 100 \\
\hline $\begin{array}{c}\text { main control } \\
\text { room, } \\
\text { computer } \\
\text { room }\end{array}$ & 16.0 & 14.0 & 500 \\
\hline $\begin{array}{c}\text { electronic } \\
\text { equipment } \\
\text { room }\end{array}$ & 9.5 & 8.0 & 300 \\
\hline $\begin{array}{c}\text { coal, water } \\
\text { control room }\end{array}$ & 9.5 & 8.0 & 300 \\
\hline $\begin{array}{c}\text { high and low } \\
\text { voltage power } \\
\text { distribution } \\
\text { room }\end{array}$ & 7.0 & 6.0 & 200 \\
\hline $\begin{array}{c}\text { cable } \\
\text { interlayer }\end{array}$ & 3.0 & 3.0 & 50 \\
\hline $\begin{array}{c}\text { underground } \\
\text { coal } \\
\text { unloading, } \\
\text { coal pier }\end{array}$ & 3.0 & 3.0 & 300 \\
\hline
\end{tabular}

The main ways of energy-saving lighting:

(1)The vigorous use of energy-efficient electric light source and lighting electrical accessories.

(2) The selection of lighting efficiency, reasonable light distribution.

(3) The scientific and reasonable design of energysaving lighting control and optimization.
In addition, a good job in daily maintenance management is important.

\subsection{The problems existing in the domestic power plant lighting design}

According to the field investigation and research in some power plants, there are the following problems in the power plant lighting:

(1) Lighting electrical products with low efficiency, short life and unstable performance.

Some power plants using low light efficiency, short life of high-pressure mercury lamp; T12 thick tube fluorescent lamp is used in a few plants, in the corridor, stair and ordinary places still use incandescent lamp as the light source. Although high efficient lamps and light source is applied in many plants, but the matching accessories of the lamp, especially advanced energysaving ballast products still cannot get due attention. Many high strength gas discharge lamps and fluorescent lamps are still equipped with the old power inductance ballast.

(2) The unreasonable lighting design

There is no use of three-phase five wire system in the longer lighting line that leading to the line loss is too large, the voltage drop, power down, and then make the illumination flux decrease; plant road lighting without using partition power supply, and adopted centralized power supply; Part of the power plant of outdoor and stair lighting control adopts optically controlled method, while adopting light-operated switch can play a certain energysaving effect during the day, but in the middle of the night, some unmanned place lamp Chang Ming will cause the waste of electricity; In selected lamps and lanterns of the plant is not suitable for light distribution curve and the exchanges, cause the cliff uneven illumination, cause the intensity of illumination is too centralized or decentralized; The glare phenomenon is serious in centralized control room of many power plants, lamps are wrongly designed in the interference area, that leads to rework after lighting construction, it is a great waste of resources.

\section{Green lighting application in power plant}

Lighting power is the most basic power demand; the quality of lighting has a direct relationshipthe for the power plant safety production, labor productivity, labor health and occupational health.

The power plant lighting electricity consumption (L) can be expressed by the following formula:

$$
\mathrm{L}=\mathrm{WT}^{*}(\mathrm{EA} / \mathrm{FK})=\mathrm{EAT} / \mathrm{k} \eta
$$

Among:

W-electric power consumption per lamp, $\mathrm{kW} \mathrm{/}$ each;

T-time of the light turn on, $\mathrm{h}$;

E-average design illumination, $1 x$;

A-floor area, $\mathrm{m}^{2}$; ;

F-each lamp lumens, $1 \mathrm{~m}$; 
K-maintenance coefficient;

$\eta$-the comprehensive efficiency of the light bulb, F / W;

Therefore, in order to reduce lighting energy consumption, it must try to use efficient lighting, increase the rate of repair of the lamps; or reduce time to turn on the lights, maintain proper illumination and maximize the use of local lighting and so on. However, energy-saving lighting is the principle of saving energy in the premise of ensuring adequate lighting brightness and quality. Thus, choose a reasonable illumination (E), efficient lighting lumens (f) and improve comprehensive efficiency ( $\eta$ ), strengthening the operation management, have very important significance for energy-saving lighting.

Lighting energy saving measures in power plant should start with the lighting design. Advanced technology, reasonable economy, the use of safe, convenient maintenance and management should be ensured to promote green lighting project in comprehensive engineering application and promotion.

\subsection{High efficiency energy-saving electric light source and lighting accessories}

Production and application of high quality and efficient lighting equipment is an important means for the implementation of green lighting, one of the most important is efficient light source. There are different types of efficient light source which have their own characteristics and applicable places; they should be selected by using conditions and requirements.

Compact fluorescent lamps (energy-saving lamps) compact size, easy to use, equipped with electronic ballast, which have good color, no flicker, light efficiency higher merit, can very convenient alternative to incandescent lighting light source. High power tube diameter straight tube fluorescent lamps and highstrength gas discharge lamp (HID) have the higher light efficiency, more advantages in price performance ratio, and is suitable for different use places.

In the comprehensive promotion and selection of various types of efficient light source at the same time, we should also pay attention to the application of efficient lighting and light source accessories, especially the advanced and energy-saving lamps and other lighting accessories.

\subsubsection{The light source}

Light source with high luminous efficiency, long life should be used, such as thin and straight tube fluorescent lamp, compact type fluorescent lamp and metal halide lamp, high pressure sodium lamp. It is better to use the general color rendering index $(\mathrm{Ra})$ that greater than three fluorescent lamp 80 in adopting fluorescent lamp. The height of the lower room should adopt thin and straight tube fluorescent lamp, compact fluorescent lamp and low power metal halide lamp. High industrial plant and should be according to the requirement of production,or using metal halide lamp and high-pressure sodium lamp, using high power thin and straight tube fluorescent lamp.
Compact fluorescent lamp,also called single ended fluorescent lamp,or energy saving lamp. Energy-saving lamps more structural type, good color, the color is strong; high light efficiency is 5-7 times that of incandescent lamp; long service life is 5 times that of incandescent lamps, the average service life of 5000 hours, under the condition of low voltage can start lighting, and can achieve the normal voltage brightness, and no noise and flashes of light. At the power plant, corridors, staircases, toilet, coal handling system, coal layer, grey base places can be substantial use energy-saving lamps.

The light source is required three factors, namely: high luminous efficiency, long life, high color. The main parameters of the common light source refer to table 3 .

Table 3. Luminous efficiency and technical parameters of common light source.

\begin{tabular}{|c|c|c|c|}
\hline $\begin{array}{l}\text { Type of light } \\
\text { source }\end{array}$ & $\begin{array}{c}\text { Rated } \\
\text { power } \\
(\mathrm{W})\end{array}$ & $\begin{array}{c}\text { luminous } \\
\text { efficiency } \\
(1 \mathrm{~m} / \mathrm{W})\end{array}$ & $\begin{array}{l}\text { service life } \\
\text { (h) }\end{array}$ \\
\hline $\begin{array}{c}\text { Ordinary } \\
\text { incandescent } \\
\text { lamp }\end{array}$ & $15 \sim 1000$ & $7 \sim 19$ & $1000 \sim 1500$ \\
\hline $\begin{array}{c}\text { Tungsten } \\
\text { halogen lamp }\end{array}$ & $500 \sim 2000$ & $19.5 \sim 21$ & 1500 \\
\hline $\begin{array}{c}\text { Fluorescent } \\
\text { lamp (T8) }\end{array}$ & $18 \sim 58$ & $75 \sim 86$ & $8000 \sim 10000$ \\
\hline $\begin{array}{l}\text { Fluorescent } \\
\text { lamp (T5) }\end{array}$ & $14 \sim 80$ & 78.5 94 & $8000 \sim 12000$ \\
\hline $\begin{array}{c}\text { Compact } \\
\text { fluorescent } \\
\text { lamp }\end{array}$ & $5 \sim 36$ & $57 \sim 80.5$ & $4000 \sim 15000$ \\
\hline $\begin{array}{l}\text { High pressure } \\
\text { mercury lamp }\end{array}$ & $80 \sim 400$ & $47.5 \sim 55$ & $2500 \sim 5000$ \\
\hline $\begin{array}{c}\text { Tube type } \\
\text { hernia lamp }\end{array}$ & $\begin{array}{c}1500 \sim 1000 \\
00\end{array}$ & $20 \sim 37$ & $500 \sim 1000$ \\
\hline $\begin{array}{l}\text { High pressure } \\
\text { sodium lamp }\end{array}$ & $50 \sim 1000$ & $68 \sim 128$ & $2400 \sim 32000$ \\
\hline $\begin{array}{l}\text { Metal halide } \\
\text { lamp }\end{array}$ & $70 \sim 1000$ & $75 \sim 110$ & $9000 \sim 20000$ \\
\hline
\end{tabular}

\subsubsection{Energy saving comparison}

Energy saving compared with high efficiency and energy saving light source (the same illumination) is shown in table 4 .

Table 4. Energy saving comparison of energy-saving light source.

\begin{tabular}{|c|c|c|c|}
\hline $\begin{array}{c}\text { Ordinary } \\
\text { incandescent } \\
\text { lamp(W) }\end{array}$ & $\begin{array}{c}\text { Self ballast } \\
\text { compact } \\
\text { fluorescent } \\
\text { lamp } \\
(\mathrm{lm} / \mathrm{W})\end{array}$ & $\begin{array}{c}\text { Power } \\
\text { saving effect }\end{array}$ & $\begin{array}{c}\text { Power saving } \\
\text { rate }\end{array}$ \\
\hline 100 & 25 & 75 & 75 \\
\hline 60 & 16 & 44 & 73 \\
\hline 40 & 10 & 30 & 73 \\
\hline
\end{tabular}


It can be seen that the use of efficient energy-saving light source, has the following advantages: saving energy, prolong life, improve light efficiency, reduce material consumption, etc.. When the rated life is long, the energy saving effect is more obvious.

The use of energy-saving lamps can save electricity charges about 28 yuan than incandescent lamp per year, to the metal halide lamp and mercury lamp, the power savings is about 544 yuan a year.(Compared with mercury lamp, metal halide lamp can save electricity charges about 544 yuan per one per year) On the engineering, 2 units of $660 \mathrm{MW}$ unit new factory use about 1000 fluorescent lamps, metal halide lights around 1100. If we use high efficiency and energy saving light source, it can save electricity of about 620000 yuan a year.

\subsubsection{The LED light source}

Compared with other light sources, LED is a new energysaving light source which has the advantages such as: luminous efficiency highest, the longest life expectancy, color performance is good, energy saving and environmental protection, long service life, security, small volume, high flicker, convenient regulation and control. The disadvantage is that the stability of product quality is poor, service life and theory of life vary widely, the price is higher than other gas discharge light source several times. The technical indices of the common LED lamp are shown in table 5 .

Table 5. The technical indices of common LED lamp.

\begin{tabular}{|c|c|c|c|c|}
\hline Name & Mode & $\begin{array}{c}\text { Working } \\
\text { voltage } \\
(\mathrm{V})\end{array}$ & $\begin{array}{c}\text { Power } \\
(\mathrm{W})\end{array}$ & $\begin{array}{c}\text { Lamp } \\
\text { holder } \\
\text { model }\end{array}$ \\
\hline $\begin{array}{c}4.8 \mathrm{~V} \text { red } \\
\text { LED }\end{array}$ & L-ZE06R & 4.8 & 0.6 & $\mathrm{E} 27$ \\
\hline $\begin{array}{c}4.8 \mathrm{~V} \text { green } \\
\text { LED }\end{array}$ & L-ZE06G & 4.8 & 0.6 & $\mathrm{E} 27$ \\
\hline $\begin{array}{c}\text { 12V yellow } \\
\text { LED }\end{array}$ & L-ZF10Y & 12 & 1.2 & $\mathrm{E} 27$ \\
\hline $\begin{array}{c}12 \mathrm{~V} \text { blue } \\
\text { LED }\end{array}$ & L-ZF24B & 12 & 2.4 & $\mathrm{E} 27$ \\
\hline $\begin{array}{c}\text { Three colours } \\
\text { lamp }\end{array}$ & D3F & 12 & 0.6 & $\mathrm{E} 27$ \\
\hline $\begin{array}{c}\text { Candle lamp } \\
\text { ZGE }\end{array}$ & 12 & 1.25 & $\mathrm{E} 27$ \\
\hline
\end{tabular}

\subsubsection{Lighting accessories}

Accessories for common lamps are: ballast, starter, trigger and capacitor. The energy consumption of the ballast is generally accounted for $20 \% \sim 30 \%$ of the energy consumption of the whole lamp, so the selection of ballast is mainly studied. The commonly used ballast is divided into two categories: inductive ballast and electronic ballast. The inductive ballast is divided into two types: traditional type and energy saving type.
$36 \mathrm{~W} / 40 \mathrm{~W}$ performance comparison of various ballast, see table 6 .

Table 6. Comparison of energy-saving inductance ballast and electronic ballast.

\begin{tabular}{|c|c|c|c|c|}
\hline Model & $\begin{array}{c}\text { Self } \\
\text { power } \\
\text { consumpt } \\
\text { ion } \\
\text { (W) }\end{array}$ & $\begin{array}{c}\text { Price } \\
\text { ratio }\end{array}$ & $\begin{array}{c}\text { Light } \\
\text { efficiency } \\
\text { ratio }\end{array}$ & $\begin{array}{c}\text { Boot } \\
\text { surge( } \\
\text { times) }\end{array}$ \\
\hline $\begin{array}{c}\text { Ordinary } \\
\text { inductance } \\
\text { ballast }\end{array}$ & 9 & 1 & $0.95 \sim 0.98$ & 1.5 \\
\hline $\begin{array}{c}\text { Energy- } \\
\text { saving } \\
\text { inductance } \\
\text { ballast }\end{array}$ & $4 \sim 5.5$ & 1.6 & $1.02 \sim 1.05$ & 1.5 \\
\hline $\begin{array}{c}\text { Domestic } \\
\text { standard } \\
\text { electronic } \\
\text { ballast }\end{array}$ & $\leqq 3.5$ & $3 \sim 4$ & 1.10 & $10 \sim 15$ \\
\hline $\begin{array}{c}\text { Imported } \\
\text { electronic } \\
\text { ballast }\end{array}$ & $\leqq 3.5$ & $4 \sim 7$ & 1.10 & $8 \sim 10$ \\
\hline $\begin{array}{c}\text { Domestic H } \\
\text { type } \\
\text { electronic } \\
\text { ballast }\end{array}$ & $\leqq 3.5$ & $1.3 \sim 1.8$ & 1.10 & $15 \sim 20$ \\
\hline
\end{tabular}

\subsubsection{Lighting lamps with high efficiency and light distribution}

We should choose reasonable light distribution, high reflectivity and good durability of the reflective lamp. To improve the utilization rate of the light emitted by the light source, the light energy distribution of the light source to where it is needed, to prevent glare caused by light, and the light source is not influenced by external force, damp and harmful gases.

The efficiency of the high efficiency and high quality lighting should not be less than the value in table 7 and table 8 .

Table 7. The efficiency of fluorescent lamps.

\begin{tabular}{|c|c|c|c|c|}
\hline \multirow{2}{*}{$\begin{array}{c}\text { The lamp } \\
\text { light outlet } \\
\text { form }\end{array}$} & Open & \multicolumn{2}{|c|}{$\begin{array}{c}\text { Protective cover (glass } \\
\text { or plastic) }\end{array}$} & \multirow{2}{*}{ grille } \\
\cline { 3 - 4 } & & Transparent & $\begin{array}{c}\text { Frosted } \\
\text { prism }\end{array}$ & \\
\hline $\begin{array}{c}\text { Lamp } \\
\text { efficiency }\end{array}$ & $75 \%$ & $65 \%$ & $55 \%$ & $65 \%$ \\
\hline
\end{tabular}

Table 8. The efficiency of high strength gas discharge lamp.

\begin{tabular}{|c|c|c|}
\hline $\begin{array}{c}\text { The lamp } \\
\text { light outlet } \\
\text { form }\end{array}$ & Open & Grille or transparent cover \\
\hline $\begin{array}{c}\text { Lamp } \\
\text { efficiency }\end{array}$ & $75 \%$ & $60 \%$ \\
\hline
\end{tabular}




\subsection{Scientific energy-saving lighting design}

\subsubsection{Setting reasonable illumination value}

The different working place of the power plant requires different illumination. A point on the surface of the illumination is incident on the bin contains point of luminous flux, divided by the bin area. The average illumination can be calculated by using the coefficient method.

$$
E_{c}=\frac{\Phi \times N \times C U \times K}{A}
$$

Among:

$E_{c}$-average illumination of working face (1x);

$\Phi$-light flux (lm);

$N$-number of light sources (sets);

$K$-lamp maintenance coefficient, depending on the room's pollution level and the cleaning cycle of the room and lighting;

$A$ - Area of working faces $\left(\mathrm{m}^{2}\right)$;

$C U$-Utilization coefficient, generally provided by the lamps and lanterns manufacturer.

According to the requirements of visual work in each work place, the illumination standard value (average illumination value) of each place is determined. In the actual design, design allows the illuminance value deviation and standard value of 10 . Of course, the selected illuminance values should take the feel of people working in this environment into consider, to ensure that there is a certain degree of visual satisfaction, 100 3001x range is the most continuous work of the indoor environment of the appropriate illumination.

\subsubsection{Reasonable and integrated lighting layout}

It should be based on the use of light sources, can not blindly pursue the uniform distribution of light.

On the one hand, the comprehensive utilization of general lighting and local lighting mixed lighting. General lighting just to satisfy the basic requirement of illumination, it should set local lighting in a special places (such as high and low pressure heater water level gauge of the main building and deaerator water level meter, etc.). On the other hand, make full use of natural light, the correct choice of natural lighting. In the workshop design of building, if possible, the window settings should be the most of the sun, from a number of points rather than from a injection workshop, and no harsh feeling, it is best to make the sunshine from both sides of the incident, so the incoming light is uniform.

At the same time, make full use of indoor smooth reflective, can effectively improve the utilization rate of light, such as the white walls of the reflection coefficient is up to $70 \% \sim 80 \%$, it can also play a very good energy saving effect.

\subsubsection{Reasonable lighting control mode}

Reasonable lighting control is an important means to achieve energy saving. Using intelligent lighting controller, through the energy saving control module and energy optimization algorithm, so that the lamp work in the best condition. Using the combination of centralized control and local control mode of lighting switches, the position and number of the indoor switch should be appropriate to according to the needs of the light turn on or turn off the light, so as to achieve energy-saving.

Boiler body, roads and other places of outdoor lighting should adopt the method of synchronous reduce the luminous flux, it is in the line of lamps and lanterns control module, when outdoor lighting free will all light flux decrease to the same level, both to ensure the illumination function and achieve energy saving purpose. Corridors and stairwells can use acoustic, electric or compound control mode.

\subsubsection{Reasonable power supply mode and line}

It is appropriate to install the compensation capacitor, to ensure its power factor in the place for a large amount of gas discharge lamps. Consider adding capacitance compensation function in the electronic ballast, will enable the loss reduction, a reasonable choice of wire cross is selected based on the calculation.

Optimizing distribution mode. Replace single-phase power supply with three phase four wire, the line loss can be 75 80 lower than the original. We should use threephase four-wire circuit in the long lighting, such as the lighting circuit of roads and coal pier; In addition, the voltage change of the power plant between day and night often form 5 to12, after midnight, the line voltage higher than rated value $3 \sim 5$, this time running lights power often exceeds the rated value by $10 \%$, high voltage is not only a waste of energy but also shorten the service life of the lights. The pressure limiting measures can be adopted, one is to use the limiting pressure of the reactor, and the other is to use the thyristor to control the voltage.

\subsubsection{Safety of lighting system}

The safety lighting system should include two aspects: on the one hand, the safety of the lighting system itself, on the other hand, it is the emergency lighting system which is relative to the normal lighting.

In order to ensure the safety of the lighting system itself, all the live parts of the lamp must be separated by insulating material, which is known as the protection against electric shock. According to the calculated current of each wire to verify the calculation of the current to select the conductor section, the boiler body and other high temperature sites should use heat conductor. Lighting distribution lines and branch lines shall use copper wire or cable, and the section of the branch shall be not less than $2.5 \mathrm{~mm}^{2}$. At the same time, all the socket circuit should be based on single-phase three wire wiring (with protection line), the branch circuit conductor section of the minimum is $2.5 \sim 4 \mathrm{~mm}^{2}$. 


\subsubsection{Good maintenance and management}

The lighting value of the lighting equipment will fall after the use of a period of time, we should clean lighting lamps regularly, and replace the light source in accordance with the normal maintenance procedures. Regularly check the lamp shade, if its aging or discoloration, should be replaced in a timely manner to improve the light transmission efficiency of lamps and lanterns. At the same time, with the convenient maintenance and cleaning of the new type of lamp replacement of old or damaged lamps, can also be divided into areas for the measurement and assessment of electricity, effective energy saving.

\section{Concluding remarks}

Power plant electrical lighting is a comprehensive discipline, it should fully understand the structure of the building structure, process requirements under the premise of comprehensive consideration of economic, energy saving, rationality. The economy should not only focus on the number of initial investment, but also take into account the total annual lighting costs (equipment depreciation costs, management fees and the sum of the electricity tariff). Under the same illumination conditions, should give priority to select the lamps and lanterns of luminous efficiency highest lighting light source and the efficiency of the highest, at the same time from lighting design, lighting control, makes use of natural light and other aspects of strengthening maintenance and management, in order to obtain the double benefits of lighting and energy-saving.

There is no doubt that the promotion and use of green lighting has a very important significance to energy saving of lighting in power plant, it also in line with the green lighting energy policy. In power plant, reasonable selection of efficient energy-saving lamps and lanterns in lighting energy-saving design, electric light source and accessories, the improvement of lighting electricity utilization rate and effective control, will gain great social and economic benefits.

\section{References}

1. W. Hongmei, L. Ke, Technology Innovation and Application, 16,26(2013)

2. Y. Sufang, Chinese Consulting Engineers,3,51(2013)

3. W. Chenghui,Scinence and Technology\& Innovation, 7,66(2014)

4. R. Wenguang, L. Kun, Q. Haixian, Telecom Word, 15,93(2014)

5. L. Qishu, C. Ming, Technology Wind,125(2014)

6. C. Haihua, Zhejaing Electric Power,9,29(2013)

7. Z. Li, Technology Wind,133(2014)

8. T. Lianhua, Guangdong Science \& Technology, 20, 93(2013)

9. L. Xiang, L. Lingru, Journal of Jiangxi Vocational and Techincal College of Electricity,3,16(2011)

10. S. Jingyu, Construction\&Design for Engineering, 65(2008)
11. L. Guangxing, Inner Mongolia Water Resources, 1, 42(2013)

12. H.Rong,Sichuan Electric Power Technology, 12, 55(2009)

13. S.Dianyang,R.Yan,Y.Di,Lamps and Lighting, 3, 45(2014)

14. L.Song,Z.Kailin, Guangdong Science\&Technology, 22, 126(2013)

15. L. Hong, G. Fei, China Illuminating Engineering Journal, 2,6(2006)

16. Z. Huangchagn, China Planning Press,DL/T 53902014 